\title{
Intellectual Capital Performance of the Commercial Banking Sector of Malawi
}

\author{
Andrew Munthopa Lipunga ${ }^{1}$ \\ ${ }^{1}$ Department of Accountancy, University of Malawi-The Polytechnic Blantyre, Malawi \\ Correspondence: Andrew Munthopa Lipunga, Department of Accountancy, University of Malawi-The \\ Polytechnic, Private Bag 303, Chichiri, Blantyre 3, Malawi. Tel: 999-694-031. E-mail: alipunga@poly.ac.mw
}

Received: October 14, 2014

Accepted: November 14, 2014

Online Published: December 20, 2014

doi:10.5539/ijbm.v10n1p210

URL: http://dx.doi.org/10.5539/ijbm.v10n1p210

\begin{abstract}
In the current knowledge-based economy, the importance of intellectual capital as a factor of competitive advantage is undisputable. This is particularly true for the banking sector in which intellectual capital efficiency is critical for development of a cutting edge strategy. The purpose of the study was to measure the intellectual capital efficiency of the commercial banking sector of Malawi. The study used the value added intellectual capital coefficient $\left(\mathrm{VAIC}^{\mathrm{TM}}\right.$ ) in order to measure performance, from 2010 to 2013 plus the performance level categorisations employed in Kamath (2007). The results indicate that the sampled commercial banks achieved on average, common performance in all the years under study, except in 2011 when they achieved good performance. Furthermore the trend analysis suggested an upward trend in terms of the level of efficiency, however at a very low rate. This suggests that the commercial banks have to put more effort to improve their intellectual capital efficiency. Furthermore, consistent with other prior studies, the study found that human capital efficiency of the sampled banks was relatively higher than structural capital and capital employed efficiencies over the entire period. This confirms the significance of human capital to value creation for the banks, hence a need for the management of the banks to pay required attention to their employees.
\end{abstract}

Keywords: Intellectual capital, value added intellectual coefficient $\left(\mathrm{VAIC}^{\mathrm{TM}}\right)$, Malawi

\section{Introduction}

Entity resources are the most significant necessity for realizing and maintaining competitive advantage (Janosević et al., 2013). In today's economy which is knowledge-based (Gan \& Saleh, 2008), wealth and growth are predominantly driven by intangible assets (Cabrita \& Vaz, 2005). This highlights the fact that the value created in this new economy depends far less on physical assets and more on intangible ones (Cabrita \& Vaz, 2005). This fact is recognised globally hence the global market is progressively moving towards knowledge and technological innovation, seeking methods to boost competitive advantage (Maditinos et al., 2009). This signifies a shift from traditional work environment towards the situation that knowledge and skills of employees are the chief productive element in the economy (Litschka et al., 2006). Latif et al. (2012) also recognised that $21^{\text {st }}$ century is a century of knowledge economy, as there is a move from production era to knowledge era and from production labour to knowledge worker. Thus intangible assets are gaining prominence than ever before as a matter survival and of achieving competitive advantage for the organisations. These intangible assets collectively are referred to as intellectual capital. They are called "intellectual" simply because their source is the human mind (Janosević et al., 2013). However, though they are products of human mind hence intangible or invisible drivers (i.e. intangible competencies), they create not only "intangible goods" (such as know-how, licenses, patents, franchises, copyrights, trademarks, software and methods), but also invisible competences or competitive advantages and lastly real common tangible assets (Mavridis, 2004).

According to Janosević et al. (2013) intellectual capital has been defined in various ways due to its heterogeneous nature. These definitions though different they consensually stress on the intellectual capital's potential benefits and its reliance on non-material resources (Janosević et al., 2013). Mondal and Ghosh (2012) described intellectual capital as "intangible assets or intangible business factors of the company, which have a significant impact on its performance and overall business success, although they are not explicitly listed in the balance sheet (if so, then under the term goodwill)." According to Yalama and Coskun (2007) intellectual capital is "something which already exists in a firm but cannot be seen on its balance sheet exactly, a competitive 
advantage over the firm's competitors, future values and includes all its intangible assets, the value of knowledge, information, intellectual property and experience, a key factor influencing the future value of the firm." Cabrita and Vaz (2005) simply stated that intellectual capital is a matter of creating and supporting connectivity between all sets of expertise, experience and competences inside and outside the organization.

Due to the importance of intellectual capital to the organisations and the change in the operating environment, it is logically expected that there will be a corresponding change in focus in the management of the entities. However, Litschka et al. (2006) observed that managerial awareness regarding the significance of human and intellectual capital was still low. This may suggest that less is been done to increase awareness or the managers are still having the production era mind set hence unable recognise the environmental changes and interpret accordingly or are unable to clearly understand the awareness been brought to their attention. There is therefore a need for enhanced effort leading to greater managerial awareness on the subject. Furthermore, despite the popularity of intellectual capital among the research community in the developed world, there have been very few studies that have used emerging economies as a case for evaluating the implications of intellectual capital for specific industries (Kamath, 2007). This is a gap that needs filling, because with the globalization, all organizations [both in developed and developing economies] are increasingly confronted with worldwide competition (Muhammad \& Ismail, 2009), which is making intellectual capital equally important to all of them to survive. Thus there is equally a need to promote studies in developing countries.

Generally the importance of intellectual capital transcends sectoral differences however it is particularly critical to the banking sector. The business nature of the banking sector is "intellectually" (or personnel) intensive and its staff is (intellectually) more homogenous than in other economy sectors (Mavridis, 2005). Generally banks use a huge amount of human capital and customer capital for their survival (Kamath, 2007); hence banking sector is described as knowledge-intensive, skills-based and relationship-rich industry (Muhammad and Ismail, 2009). Typically banking operations involve close interaction with customers and rely, to a larger extent, on the integration of information and communication technologies for the development of new products and services (Mention \& Bontis, 2013). As a result, although physical capital is essential for banks to operate, it is the intellectual capital that determines the quality of services provided to customers (Goh, 2005). Furthermore, the importance of intellectual capital to the banking sector is exacerbated by the increasing complexity and a more liberal environment that the banks are current operating in, in which competitiveness depends critically on the quality of human intellectual capital and the ability to leverage on these talents (Muhammad and Ismail, 2009). Thus due to the competitiveness and dynamism of the current operating environment, intellectual capital efficiency is critical for banks to develop a cutting edge strategy (Joshi et al., 2010).

The paper endeavours to measure intellectual capital performance (efficiency) of the commercial banking sector a developing economy, Malawi. The study has practical significance to the country as a whole and to the banking sector in particular and scientifically. The country (Malawi) is developing and generally economic growth of a country is influenced by the performance of the banks and furthermore the performance of other business organizations in an economy is also dependent upon the service provided by the banking sector (Mondal \& Ghosh, 2012). As indicated above, in current era, intellectual capital is critical to the vibrancy of the banking sector and hence to the economy. This is why it is important to examine to what extent banks are capable of utilizing the intangible or intellectual assets (Mondal \& Ghosh, 2012), knowing that the same has wider implications on the wellbeing of the entire economy. The study furthermore, informs the practitioners in the banking sector in Malawi of the current intellectual capital performance of the banks and the needed improvements in order to enhance it. On the other hand, as generally there is dearth of literature on intellectual capital in developing economies (Abeysekera, 2007; Khan \& Ali, 2010); the study therefore enriches existing literature by providing empirical evidence of intellectual capital performance taking a case of commercial banking sector from a developing country. Besides, being the first study of its kind in Malawi, the study acts as a future reference source. The remainder of the paper is structured as follows. Section two provides the review of prior studies on intellectual capital performance and value added intellectual coefficient (VAIC ${ }^{\mathrm{TM}}$ ) methodology, followed by section three that gives the description of the study's research methodology. Section four presents the results of analysis and the discussion thereafter section five gives the concluding remarks.

\section{Literature Review}

\subsection{Intellectual Capital Performance}

Generally intellectual capital research is scarce in developing economies (Abeysekera, 2007; Khan \& Ali, 2010). In Malawi there has not been any empirical study on intellectual capital performance of the commercial banks. However, the only study on intellectual capital of banks was a visualisation of intellectual capital disclosures in 
the annual reports of the banks by Lipunga (2013). The purpose of the study was to visualise the extent of intellectual capital disclosures in the annual reports of the banks. As such the study did not measure the intellectual capital performance. Another study generally on the topic, Lipunga (2014) was a longitudinal assessment of the level of intellectual capital on the companies listed on the Malawi Stock Exchange for a five year period 2008-2012. The study measured the values of intellectual capital and not the efficiency. However using the market-to-book value method, the results of the study suggested that intellectual capital was a significant part of the total value of the listed companies.

On the other hand, there has been prior studies measuring intellectual capital performance and determining factors that influence performance in various sectors including the banking sector in other countries. In Malaysia, Goh (2005) measured the intellectual capital performance of commercial banks for the period 2001 to 2003. The study used efficiency coefficient called value added intellectual coefficient (VAIC ${ }^{\mathrm{TM}}$ ). The findings indicated that all banks had relatively higher human capital efficiency than structural and capital employed efficiencies, which meant that human capital was contributing more to the banks' value added. Furthermore Goh (2005) found that domestic banks were generally less intellectually efficient compared to foreign banks. Consistent results were also found in Indian banking sector, where evident bias was found in favour of the performance of foreign banks compared with domestic banks (Kamath, 2007). Goh (2005) further found significant differences between rankings of banks according to intellectual capital efficiency and traditional accounting measures. The findings may not be surprising as according to Tseng and Goo (2005), traditional accounting measures are generally inadequate for determining real corporate value in the knowledge-based economy. Mohiuddin et al. (2006) also intimated that there is lucid evident that the traditional accounting methods are losing their way at the advent of dynamic changes taking place in today's business.

Studying the relationship of intellectual capital to business performance, Mention and Bontis (2013) found from 200 banking institutions within Luxembourg and Belgium that human capital was both a direct and an indirect contributor to business performance. Structural and relational capitals were found to be positively related to business performance; however results suggested statistically insignificant relationship. Consistent results were found by Mohiuddin et al. (2006) in 17 sampled commercial banks in Bangladesh for the period from 2002 to 2004. Kamal et al. (2012) on another hand studied to determine the relationship between the level of intellectual capital efficiency in terms of human capital, capital employed and structural capital with the commercial banks performance from the traditional accounting based perspective that comprised return on assets and return on equity. The overall results exhibited existence of the relationship between intellectual capitals with performance of 18 commercial banks. Additionally, the results revealed significance impact of intellectual capital variables namely value added capital employed, value added human capital towards bank performance. Thus Kamal et al. (2012) concluded that intellectual capital do matters and should be linked to firm productivity.

Ting and Lean (2009) examined the intellectual capital performance and its relationship with financial performance of financial service sector as a whole in Malaysia for the period 1999 to 2007. They found that $\mathrm{VAIC}^{\mathrm{TM}}$ and return on assets are positively related. Further to that the results also revealed that the three components of VAIC ${ }^{\mathrm{TM}}$ were associated with profitability with the explanatory power of 71.6 per cent. Mavridis (2005) on the other hand examined influence of physical capital and human capital on a non-traditional measure the value added on the Greek banking sector. The predictive analysis revealed a normal, strong, significant and positive correlation between value added and both physical capital and human capital, however human capital was relative much higher hence concluded that "intellectual capitalists" or "knowledge workers" are strongly contributing to the success of firms and especially to value added. However, opposite results were found by Puntillo (2009), using a multiple regression analysis found that for Italian banks quoted in the three year period 2005-2007, the value of intellectual capital did not weigh upon business performance, as the variation of the dependent variables return on investments (ROI) and return on assets (ROA) was not significant relative to the variations of the explicative variable, represented by the value of human capital efficiency and structural capital efficiency.

On the non-banking sectors, studies have also shown the existence of the relationship between intellectual capital efficiency and business performance. Maditinos et al. (2009) empirically examined the four elements of intellectual capital namely human capital, customer capital, structural capital and innovation capital and their relationship with business performance for companies both in service and non-services industries listed on Athens Stock Exchange (ASE). The study found that structural capital had a positive relationship to business performance in both industries, however relatively stronger in non-service industries. Ahmad and Mushraf (2011), found positive and significant correlations between all attributes of intellectual capital namely human capital, relational capital, customer capital and structural capital and business performance among Iraqi 
companies. Moreover, a regression analysis revealed that the business performance had positive and high overall association with the four attributes. Wang and Chang (2005) investigating the interrelationship among four elements of intellectual capital in Taiwanese IT industry, found that, with the exception of human capital, the innovation capital, process capital, and customer capital all had a direct effect on performance.

Furthermore, Tan et al. (2007) investigated the association between the intellectual capital of firms and their financial performance. They used VAIC ${ }^{\mathrm{TM}}$ methodology on the data drawn from 150 publicly listed companies on the Singapore Exchange. The results showed that intellectual capital and company performance were positively related, in particular intellectual capital was found to be correlated to future company performance and the rate of growth of a company's intellectual capital was positively related to the company's performance. However it was revealed that the contribution of intellectual capital to company performance differs by industry. Phusavat et al., (2011) examined empirically the effects of intellectual capital, and its key components (e.g. human capital, structural capital, and innovation capital) on a manufacturing firm's industrial operations and performance in Thailand using VAIC ${ }^{\mathrm{TM}}$. They found that intellectual capital, positively and significantly affects a manufacturing firm's performance, having impacts on the all four performance indicators under study, i.e. return on equity, return on assets, revenue growth, and employee productivity. In addition, based on the relatively high adjusted $\mathrm{R}^{2}$, human capital exhibited a relationship with employee productivity.

On another perspective, some prior studies endeavoured to measure the interrelationship between intellectual capital elements. Generally empirical evidence indicates existence of interrelationships. For instance, Maditinos et al. (2009) found that human capital was important and positively associated to customer capital; customer capital had an influence on structural capital and innovation capital had an important and positive relationship to structural capital. Wang and Chang (2005) also found that human capital directly affects innovation capital and process capital and innovation capital directly influences process capital. F-Jardon and Martos (2009) indicated also the influence of human capital on structural capital and relational capital in the wood industries of Argentina In addition to the interrelations, literature documents the relative dominance of human capital in influencing other intellectual capital components and the overall value added intellectual coefficient. For instance, Wang and Chang (2005) found that even though human capital did not have a direct impact on business performance, it had a direct impact on the other intellectual capital elements, which in turn affected performance. Furthermore, Joshi et al. (2010) revealed that VAIC ${ }^{\mathrm{TM}}$ has a significant relation with human costs and that all Australian owned banks had relatively higher human capital efficiency than capital employed efficiency and structural capital efficiency.

Finally, empirical evidence suggests that the dominance and influence of a particular VAIC ${ }^{\mathrm{TM}}$ component differs depending on the sector or subsector. For instance, Joshi et al. (2013) found that the performance of various components of VAIC ${ }^{\mathrm{TM}}$ differs across all subsectors in the financial sector. They reported that Investment companies had high value of VAIC ${ }^{\mathrm{TM}}$ due to higher a level of human capital efficiency, as compared to banks, insurance companies, diversified financials and RIETs. Insurance companies are more focussed on physical capital rather than human and structural capital leading to lower VAIC ${ }^{\mathrm{TM}}$. Furthermore, Latif et al. (2012) carrying out a comparative study between Islamic and conventional banks, found significant association between human capital efficiency and almost all variables of corporate performance, in case of Islamic banks, and a significant relationship between capital employed efficiency and all variables of performance in case of conventional banks. Which suggested that human capital efficiency was the main predictor of corporate performance of Islamic banks, while the capital employed efficiency is the main predictor of corporate performance conventional banks.

\subsection{Value Added Intellectual Coefficient (VAIC ${ }^{T M}$ )}

At the moment there are no universally agreed methods of measuring intellectual capital performance, as a result, there is an apparent recognition of the difficulty in measuring intellectual capital performance. However, Litschka et al. (2006) suggests that there is practical possibility to come up with quantitative figure for intellectual capital and they intimated that this is useful to the promotion of intellectual capital. At the moment there are two main recognised ways in measuring performance of intellectual capital which are based on the two main intellectual capital research approaches namely the cost and value methods (Mavridis, 2004). These two methods were also recognised by Mohiuddin et al. (2006). Mavridis (2004) observes that the cost method simply tries to capture the intellectual essence through the difference between market and book value whereas the value method uses the value added intellectual coefficient $\left(\mathrm{VAIC}^{\mathrm{TM}}\right)$ developed by the Austrian Intellectual Capital Research Centre (AICRS). Unlike the cost methods, the VAIC ${ }^{\mathrm{TM}}$ does not measure the value of intellectual capital; it measures the efficiency in the utilisation of the intellectual capital (Mohiuddin et al., 2006). Since the 
measurement methods are still being developed, the $\mathrm{VAIC}^{\mathrm{TM}}$ seems to be most preferred. Generally the cost methods have the following disadvantages according to Janosević et al. (2013):

"Firstly, for companies not listed on a stock exchange, the value of IC [intellectual capital] cannot be determined. Secondly, because the measure is aggregate by nature, it is impossible to assess the individual components of IC and their contribution to value creation. Thirdly, the difference in the equation may be the result of many external factors to IC. For example, undervalued or overvalued positions of tangible assets on the balance sheet may influence the market value of stock and even market capitalization, directly affecting the value of IC determined in this way. Fourthly, the ongoing economic crisis and its impact on stock prices represent further limitations to this measure because the economic crisis has, in many successful companies, induced a "meltdown" of IC measured in this way."

On the other hand, VAIC ${ }^{\mathrm{TM}}$ is considered appropriate for organizations that are intellectually inclined (Kamath, 2007) like the banks. As already indicated, the $\mathrm{VAIC}^{\mathrm{TM}}$ method is not aimed at valuing the intellectual capital of a firm, rather it primarily measures the efficiency of firms' three types of inputs: physical and financial capital, human capital, and structural capital, namely the Capital Employed Efficiency (CEE), the Human Capital Efficiency (HCE), and the Structural Capital Efficiency (SCE) (Mohiuddin et al., 2006). Generally the efficiency of use of invested capital (both intellectual and physical) is quantified through the Value Added Intellectual Coefficient $\left(\right.$ VAIC $^{\mathrm{TM}}$ ) (Janosević et al., 2013). Thus VAIC ${ }^{\mathrm{TM}}$ is simply the sum of these three efficiencies (Goh, 2005). It is an intellectual capital performance indicator of the overall level in the utilisation of the intellectual capital. As such Goh (2005) stated that;

"as a performance indicator, the higher the VAIC ${ }^{T M}$; the better is the efficiency level of the firm. If VAIC ${ }^{T M}$ rises over time, then efficiency level improves and more value is created. On the other hand, when VAIC ${ }^{T M}$ falls, efficiency deteriorates and value is destroyed".

The advantages of VAIC ${ }^{\mathrm{TM}}$ methodology include the fact that it is practical and easy to use (Mavridis, 2004). It can be used within the organization to measure the intellectual performance over a period of time without much change in the existing business setup (Kamath, 2007). Furthermore it enables various stakeholders to effectively monitor and evaluate the efficiency of Value Added by a firm's total resources and each major resource component (Gan \& Saleh, 2008). It does not only offer the calculation of the various absolute values, but also analyzes the main contributing factors like physical capital, human capital and structural capital (Mavridis, 2005); hence it clearly depicts the contribution of each intellectual capital component to value creation (Janosević et al., 2013).

The methodology however has some limitations. In practice, it fails to precisely work out the contribution of each component to creation of value added as intellectual capital elements tend to interact (Janosević et al., 2013). It fails also to incorporate the level of company risk which is an important factor in intellectual capital value determination and to measure intellectual capital in companies with negative book value or negative operating profit (Joshi et al., 2010 citing Maditinos et al., 2011 and Chu et al., 2011). Furthermore, since VAIC ${ }^{\mathrm{TM}}$ is calculated using the financial statements of companies, it implies that the coefficient is a measure of value created in the past and not that of value creation potential (Janosević et al., 2013).

However, as pointed out by Joshi et al. (2010), despite these inherent limitations of VAIC ${ }^{\mathrm{TM}}$ methodology, its simplicity, subjectivity, reliability and comparability make it an ideal measure for the context of the present study as this study makes an original contribution to the existing intellectual capital literature by analysing intellectual capital performance of Malawian banking sector. Furthermore, majority of the sampled banks are not listed hence it will be difficult to determine the market values and lastly the aim of the study is not measuring the values of intellectual capital but the performance in terms of efficiency.

\section{Research Methodology}

\subsection{Data Collection}

Data was collected from the annual reports of the banks consistent with other related studies (Goh, 2005; Mavridis, 2005; Joshi et al., 2010; Joshi et al., 2013). The period of the study was from 2010 to 2013. Reserve bank of Malawi reports indicates that there were eleven banks operating in Malawi in 2010, 2011 (Reserve Bank of Malawi, 2010; Reserve Bank of Malawi, 2011) and twelve in 2012 (Reserve Bank of Malawi, 2012). The number was brought down to eleven in 2013 after the absorption of one of the commercial banks into the other. Thus ten banks operated throughout the period of the study and the some forms the population of the study. Annual reports for eight banks ( $80 \%$ ) were accessible thus they formed the sample for the study. The sample size is acceptable, since for descriptive studies a minimum acceptable sample size is considered ten percent of the 
population (Belal, 2001 cited in Masud \& Hossain, 2012). Furthermore the sample included the two banks that dominate the market share (i.e. approximately $50 \%$ ) measured by their volume of total assets, deposits, gross loans and capital base (Reserve Bank of Malawi, 2010; Reserve Bank of Malawi, 2011; Reserve Bank of Malawi, 2012).

\subsection{Performance Measurement}

VAIC $^{\mathrm{TM}}$ was used to measure intellectual capital performance in the banks consistent with other related studies (Mavridis, 2004; Goh, 2005; Mavridis, 2005; Mohiuddin et al., 2006; Kamath, 2007; Puntillo, 2009; Joshi et al., 2010; Joshi et al., 2013). Generally the VAIC ${ }^{\mathrm{TM}}$ identifies banks with efficiency in utilizing their capitals (Goh, 2005). It measures how effectively immobilised capital and intellectual capital contribute to the creation of business value for the firm, taking into consideration three main elements: human capital, structural capital, and physical capital (Puntillo, 2009). It gives how much new value has been created per invested monetary unit in resources (Gan and Saleh, 2008). According to the VAIC ${ }^{\mathrm{TM}}$ methodology the value added (VA) is determined as the difference between total revenues (Output) and total expenses excluding staff costs (Input) and that represents the value that has been produced in the firm through the firm's resources or capital (Mavridis, 2004). Thus the following formula is used to calculate value added:

$$
\text { Value added (VA) = Output-Input }
$$

Where:

Output $=$ gross revenues

Input $=$ total expenses - staff costs

The calculated value added figure is used to determine the efficiency levels for each of the three elements that make up the VAIC ${ }^{\mathrm{TM}}$ of the firm. As already indicated, the VAIC ${ }^{\mathrm{TM}}$ is sum of three indicators of intellectual capital efficiency namely; capital employed efficiency (CEE), human capital efficiency (HCE), and structural capital efficiency (SCE) (Gan and Saleh, 2008). Basically each efficiency level is calculated separately in order to determine the contribution of all company resources (human, structural, and physical) to the creation of value added (Janosević et al., 2013).

The first component of VAIC ${ }^{\mathrm{TM}}$ given above relates to the capital employed representing the physical and financial capital of the firm. Capital employed efficiency describes how much of the company's value added is generated with the tangible capital employed (Puntillo, 2009). The capital employed efficiency (CEE), is derived from the ratio of value added to a company's net assets (Janosević et al., 2013). The following formula is used to calculate capital employed efficiency:

$$
\text { Capital employed efficiency }(C E E)=\text { value added } \div \text { net assets }
$$

The second component of the VAIC ${ }^{\mathrm{TM}}$ relates to human capital. This is a proxy is the total staff costs during year, based on the new understanding that salaries and wages should no longer be considered as costs but as investments (Puntillo, 2009). The human capital efficiency describes the relative contribution of human resources to the creation of value added (Janosević et al., 2013). It is derived from the ratio of value added to the company's total staff costs. The following formula is used in its calculation:

$$
\text { Human capital efficiency }(H C E)=\text { Value added } \div \text { Human capital }
$$

Where: Human capital $=$ total staff costs

The last component of VAIC ${ }^{\mathrm{TM}}$ relates to structural capital. Structural capital represents everything that stays in the office when employees go home (Janosević et al., 2013), for example databases, software, manuals, treatments, organization structure etc (Ahmad and Mushraf, 2011). Structural capital is determined by subtracting human capital from the amount of value added (Puntillo, 2009; Komnenic and Pokrajcic, 2012). As such structural capital is obtained from the following formula:

$$
\text { Structural Capital }=\text { Value added }(\text { VA)-Human capital }(H C)
$$

Based on the calculated amount of structural capital, the structural capital efficiency (SCE) is derived. SCE is reflected by the share of structural capital in the total value created and is calculated as follows:

$$
\text { Structural capital efficiency }(\mathrm{SCE})=\text { structural capital } \div \text { value added }
$$

It can be noted that SCE is calculated slightly different from CEE and HCE. It is argued that there is a proportionate inverse relationship between human capital and structural capital, in the value creation process attributable to the entire intellectual capital base that necessitates the measurement difference to other ratios (Janosević et al., 2013; Komnenic \& Pokrajcic, 2012). 
Finally value added intellectual coefficient $\left(\mathrm{VAIC}^{\mathrm{TM}}\right)$ which is the overall measure of efficiency is derived from the sum of the efficiencies calculated in the three formulas above. Thus Puntillo (2009) summarised that VAICTM may be seen as the composite sum of three separate indicators:

(1) Human Capital Efficiency (HCE) - an indicator of VA efficiency of human capital;

(2) Structural Capital Efficiency (SCE) - an indicator of VA efficiency of structural capital; and

(3) Capital Employed Efficiency (CEE) - an indicator of VA efficiency of capital employed.

As a performance indicator, the aggregate coefficient provides an understanding of the general efficiency, as a result, a higher coefficient indicates greater value creation in the use of the company's resources and vice versa (Goh, 2005; Gan \& Saleh, 2008; Puntillo, 2009; Janosević et al. 2013). VAIC ${ }^{\mathrm{TM}}$ is thus calculated as:

$$
V A I C^{T M}=C E E+H C E+S C E
$$

After calculation of $\mathrm{VAIC}^{\mathrm{TM}}$, the calculated performance levels of the commercial banks were categories according the classification adopted from Kamath (2007); Table 1 presents the VAIC ${ }^{\mathrm{TM}}$ performance categories. As can be seen on the Table there are four perfo0rmance level namely top performance, good performance, common performance and lastly bad performance.

Table 1. Performance categories adopted from Kamath (2007)

\begin{tabular}{ll}
\hline Top performer & VAIC $^{\mathrm{TM}}$ score of above 5 \\
\hline Good performer & VAIC $^{\mathrm{TM}}$ score of between 4 and 5 \\
Common performer & VAIC $^{\mathrm{TM}}$ score of between 2.5 and 4 \\
Bad performer & VAIC $^{\mathrm{TM}}$ score of below 2.5 \\
\hline
\end{tabular}

\section{Results and Discussion}

This section presents the results of analysis and the ensuing discussion. The performance levels are considered at individual bank level, VAIC ${ }^{\mathrm{TM}}$ component level and overall $\mathrm{VAIC}^{\mathrm{TM}}$ level. As indicated the $\mathrm{VAIC}^{\mathrm{TM}}$ scores were sorted according to the categories used in Kamath (2007).

\subsection{Individual Bank Performance}

According to Mavridis (2005) the absolute value of $\mathrm{VAIC}^{\mathrm{TM}}$ is an indicator of how good or how bad the firm creates value added and it offers a neutral possibility to compare firms for best practicing and benchmarking. Figure 1 gives the scores for the eight sampled commercial banks over the study period.

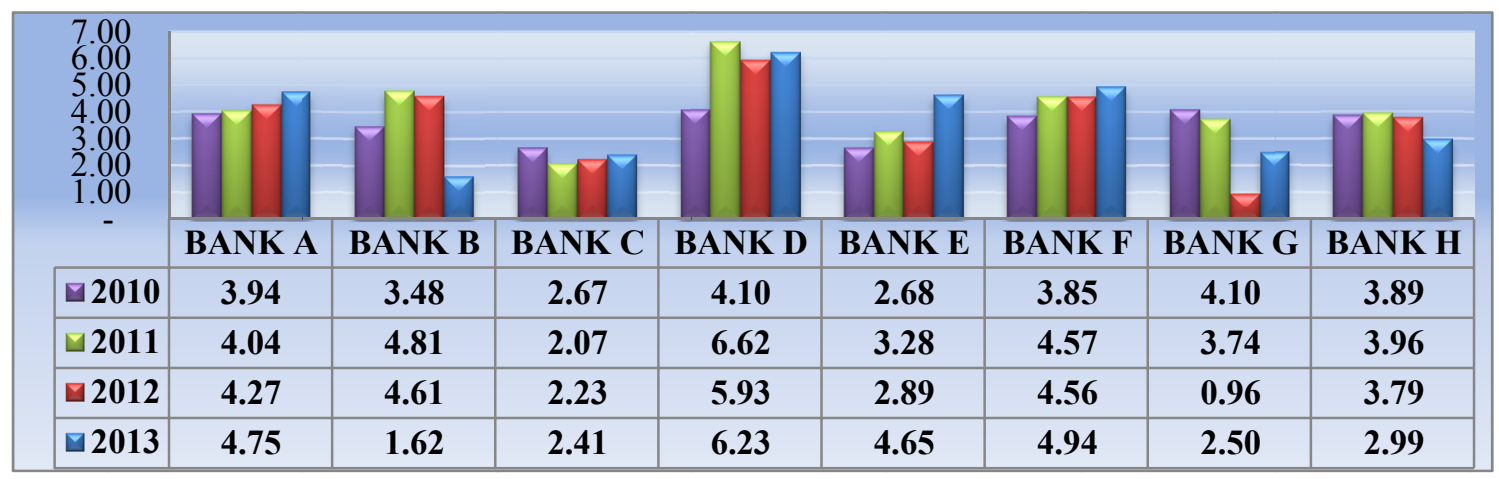

Figure 1. Individual bank VAIC scores

Furthermore, analysis of the performance frequencies is given in Figure 2. Using the Kamath (2007)'s categories, it can be noted on Figure 2 that in 2010 there was no bank in top performer category. However there were two banks $(\mathrm{D}$ and $\mathrm{G})$ that had good performance $\left(\mathrm{VAIC}^{\mathrm{TM}}=4.1\right)$, and the rest of the six banks $(\mathrm{A}, \mathrm{B}, \mathrm{C}, \mathrm{E}, \mathrm{F}$ and $\mathrm{H})$ achieved common performance. Table 2 indicates that lowest performer in 2010 had a VAIC ${ }^{\mathrm{TM}}$ of 2.67 while the highest scored 4.1. 


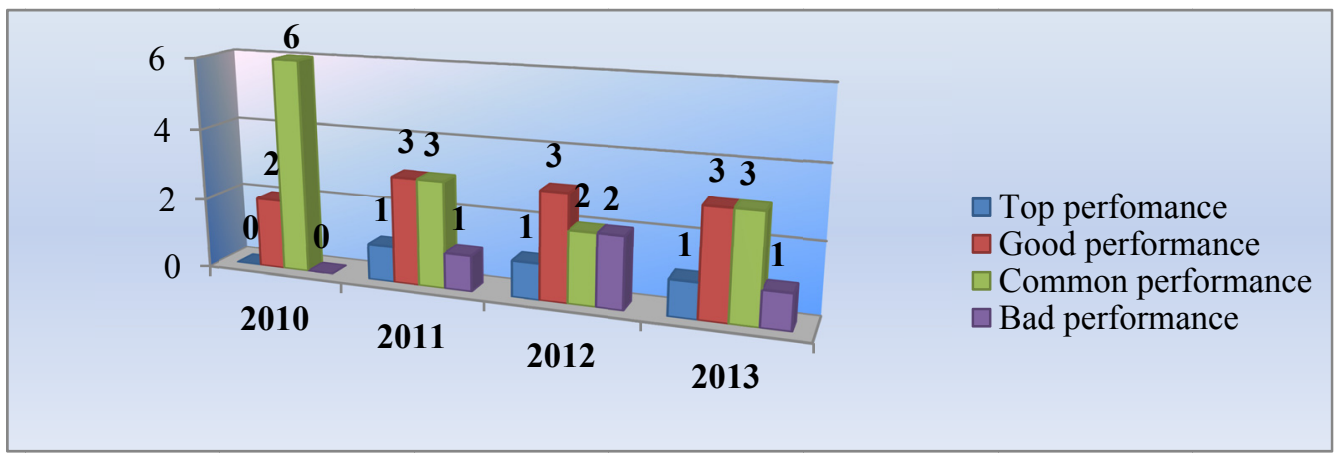

Figure 2. VAIC individual banks performance frequencies

In 2011, as exhibited in Figure 1 and 2, one bank, Bank D scored an impressive VAIC ${ }^{\mathrm{TM}}$ of 6.62 representing an increase in the coefficient of $61.5 \%$. In good performance category, there were three banks (A, B and F). Thus $50 \%$ of the sampled banks achieve better performance which was an improvement from 2010's $25 \%$. Furthermore the results shows that six banks (A, B, D, E, F and H) improved their VAIC ${ }^{\mathrm{TM}}$ scores. On the other hand three banks (E, G and $\mathrm{H}$ ) achieve common performance and one bank $(\mathrm{C})$ performed badly. Table 2 further indicates that despite the highest bank getting a better score (6.62), the lowest performed poorly (2.07), thus the performance gap between them widened greatly from 1.43 to 4.55 .

Table 2. Descriptive statistics for VAIC performance

\begin{tabular}{lllll}
\hline Period & Minimum & Maximum & Average (VAIC) & $\begin{array}{l}\text { Standard } \\
\text { Deviation }\end{array}$ \\
\hline $\mathbf{2 0 1 0}$ & 2.67 & 4.10 & 3.59 & 0.60 \\
$\mathbf{2 0 1 1}$ & 2.07 & 6.62 & 4.14 & 1.31 \\
$\mathbf{2 0 1 2}$ & 0.96 & 5.93 & 3.66 & 1.57 \\
$\mathbf{2 0 1 3}$ & 1.62 & 6.23 & 3.76 & 1.60 \\
\hline
\end{tabular}

In 2012 there was a drop in performance by the majority of the banks. According to Figure 2, bank (D) maintained the top position as a top performer, however its $\mathrm{VAIC}^{\mathrm{TM}}$ score decreased by $10 \%$. Furthermore three banks (A, B and F) also maintained their good performance, however Banks B and F registered a decrease in their VAIC ${ }^{\mathrm{TM}}$ scores whereas Bank A's score increased by 5.7\%. Bank F registering the lowest drop in the score of $0.002 \%$ while Bank B's decreased by $4.2 \%$. On the other hand, two banks ( $\mathrm{E}$ and $\mathrm{H}$ ) performed commonly while banks $\mathrm{C}$ and $\mathrm{G}$ peformed poorly. Of greatest concerned was bank G's perfomance of 0.96 that represented a drop of $74 \%$ and the lowest performance recorded over the period of the study. Furthermore the gap between the highest and lowest performers further widened from 4.55 in 2011 to 4.97 in 2012 . Besides the VAIC ${ }^{\mathrm{TM}}$ of six banks $(75 \%)$ decreased in value which was directly opposite to the 2010 performance.

However, the VAIC $^{\mathrm{TM}}$ scores of 2013 indicated a reversal of the 2012's poor performance. Figure 2 shows that in 2013 a single bank (D) had a top performing VAIC ${ }^{\mathrm{TM}}$ of 6.23 whereas three banks (A, E and F) had good performance. In the common performance category there were three banks $(\mathrm{C}, \mathrm{G}$ and $\mathrm{H})$ while a single bank (B) performed poorly. Furthermore, the results indicated that six banks $(75 \%)$ registered improvements in their $\mathrm{VAIC}^{\mathrm{TM}}$ scores and the gap between the top and lowest performers decrease to 4.61 from 4.97 in 2012. However, despite the improvements the results indicate that the two banks (B and $\mathrm{H}$ ) registered substantial decreases in their VAIC ${ }^{\mathrm{TM}}$ scores of $65 \%$ (4.61 to 1.62 ) and $21 \%$ (3.79 to 2.99 ) respectively. 
Table 3. VIAC rankings of the banks

\begin{tabular}{|c|c|c|c|c|c|c|c|c|}
\hline & 2010 & & 2011 & & 2012 & & 2013 & \\
\hline & $V I A C$ & Rank & $V I A C$ & Rank & $V I A C$ & Rank & $V I A C$ & Rank \\
\hline BANK D & 4.10 & 1 & 6.62 & 1 & 5.93 & 1 & 6.23 & 1 \\
\hline BANK G & 4.10 & 1 & 3.74 & 6 & 0.96 & 8 & 2.50 & 6 \\
\hline BANK A & 3.94 & 2 & 4.04 & 4 & 4.27 & 4 & 4.75 & 3 \\
\hline BANK H & 3.89 & 3 & 3.96 & 5 & 3.79 & 5 & 2.99 & 5 \\
\hline BANK F & 3.85 & 4 & 4.57 & 3 & 4.56 & 2 & 4.94 & 2 \\
\hline BANK B & 3.48 & 5 & 4.81 & 2 & 4.61 & 3 & 1.62 & 8 \\
\hline BANK E & 2.68 & 6 & 3.28 & 7 & 2.89 & 6 & 4.65 & 4 \\
\hline BANK C & 2.67 & 7 & 2.07 & 8 & 2.23 & 7 & 2.41 & 7 \\
\hline
\end{tabular}

Table 3 provides the rankings of the commercial banks in terms of VAIC ${ }^{\mathrm{TM}}$ performance over the period. The Table indicates that Bank D has been a consistent performer occupying the top position and was the only bank to ever achieve top performance over the period of study. On the other extreme, Bank $\mathrm{C}$ has been recording lowest or second from the lowest score. Furthermore, the Table indicates that half of the sampled banks (D, A, F and E) were better off in 2013 than they were in 2010 and the other half (G, H, B and C) got worse off. The results suggest a rather mixed picture on the individual bank performance, however it shows that more effort is needed by the individual banks to improve their $\mathrm{VAIC}^{\mathrm{TM}}$ performance.

\subsection{VAIC $^{T M}$ Components Performance}

As given above value added intellectual coefficient is a sum of human capital efficiency (HCE), capital employed efficiency (CEE) and structural capital efficiency (SCE). Figure 3 gives the percentage contribution of each component to VAIC ${ }^{\mathrm{TM}}$. Figure 3 shows that HCE contributed $66 \%, 69 \%, 66 \%$ and $67 \%$ to VAIC $^{\mathrm{TM}}$ value in 2010, 2011, 2012 and 2013 respectively. Thus the sampled commercial banks have had relatively higher human capital efficiency than structural capital and capital employed efficiencies over the entire period. This is consistent with other related prior studies (Goh, 2005; Mavridis, 2005; Muhammad and Ismail, 2009; Joshi et al., 2013). The results suggest that human capital is most dominant and more efficient in comparison to capital employed and structural capital and it strongly contributes to the corporate success and especially to its value added (Mavridis, 2005).

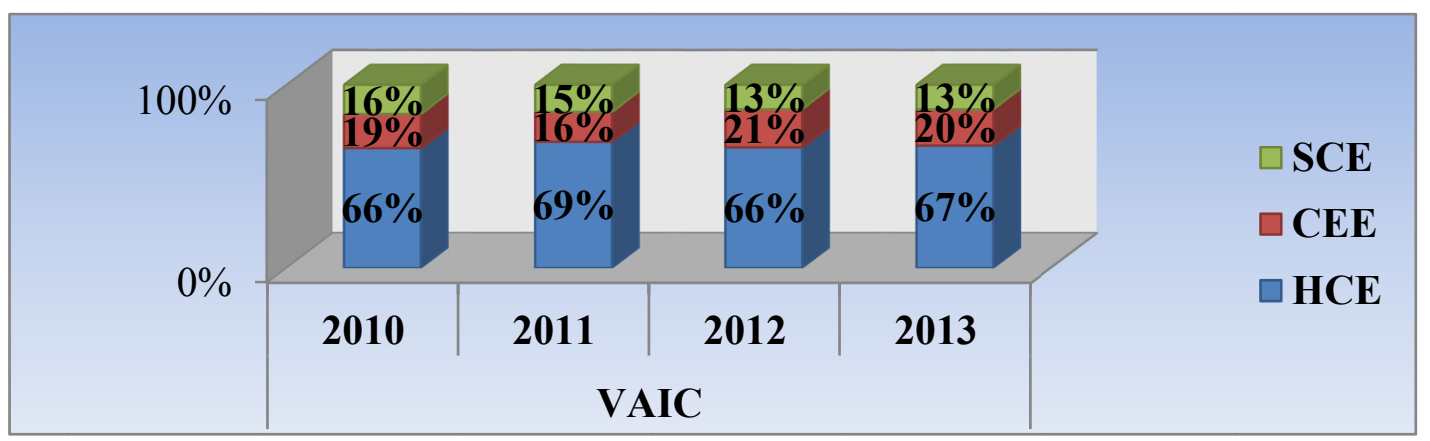

Figure 3. VAIC's components analysis

According to Mohiuddin et al. (2006), the dominance of HCE is not surprising as the banking sector is in service sector, where its customer services rely heavily on human capital. As a result value creation is highly influenced by it (Joshi et al., 2013). The study therefore provides evidence confirming that human capital is the primary leading factor of which management of the banks should put the most effort (Wang and Chang, 2005).

\subsection{Overall VAIC ${ }^{T M}$ Performance}

Figure 4 provides the average values of VAIC ${ }^{\mathrm{TM}}$ and its trend line of the over the period. As already indicated the absolute value of VAIC ${ }^{\mathrm{TM}}$ is an indicator of how good or how bad the firm creates value added (Mavridis, 
2005). Thus using Kamath (2007)'s performance categories, the results indicates that on average the sampled banks only achieved good performance in 2011, the rest of the years (2010, 2012 and 2013) they achieved common performance. The results are worrying if compared to the performance of banks in other countries. For instance in Malaysia, the VAIC ${ }^{\mathrm{TM}}$ scores ranged between 11.36 and 4.32 with an average of 7.11 and 14.62 and 6.03 with an average of 9.25 for domestic and foreign banks respectively (Goh, 2005). In India, the VAIC scores ranged between 16.24 and 5.48 with an average of 9.76 and 11.48 and 3.98 with an average of 8.85 for domestic and foreign banks respectively (Mohiuddin et al., 2006). Thus the results indicate that there is more room for improvement for the banks to enhance their value creation, hence more effort is needed to improve the efficiency levels. However on a more positive note the results suggest that the banks have the potential to achieve above average intellectual capital performance as they were able to achieve good performance in 2011.

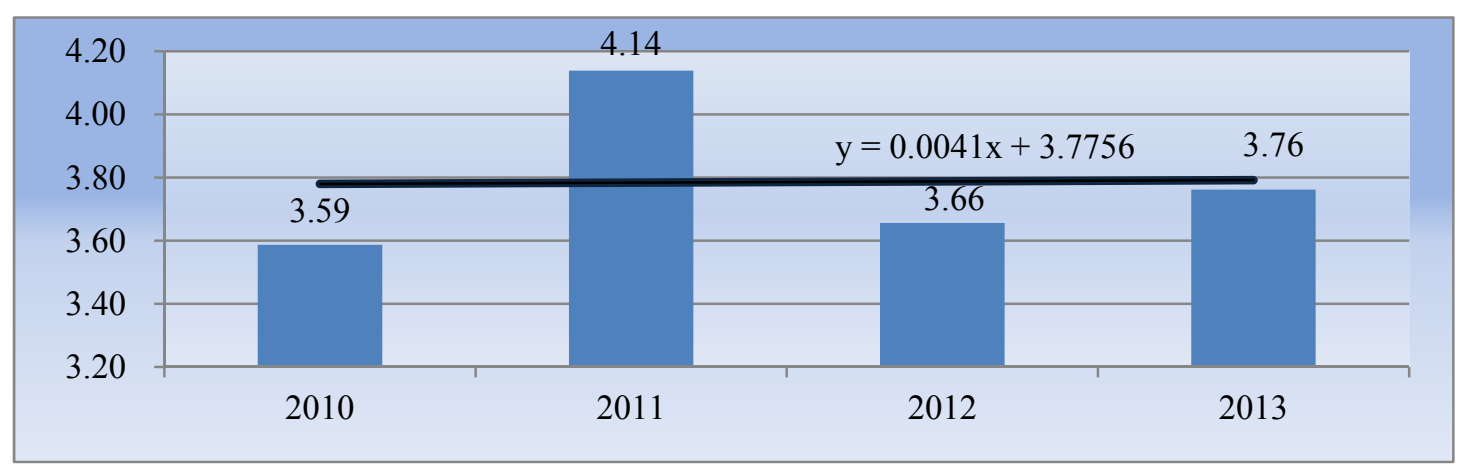

Figure 4. Overall IC performance

The trend line of VAIC ${ }^{\mathrm{TM}}$ as shown by Figure 3 indicates an upward trend, however the gradient suggests very low rate of change. This analysis further supports the need for significant amount of effort in order for the banks to improve the overall intellectual capital efficiency of the banking industry in Malawi.

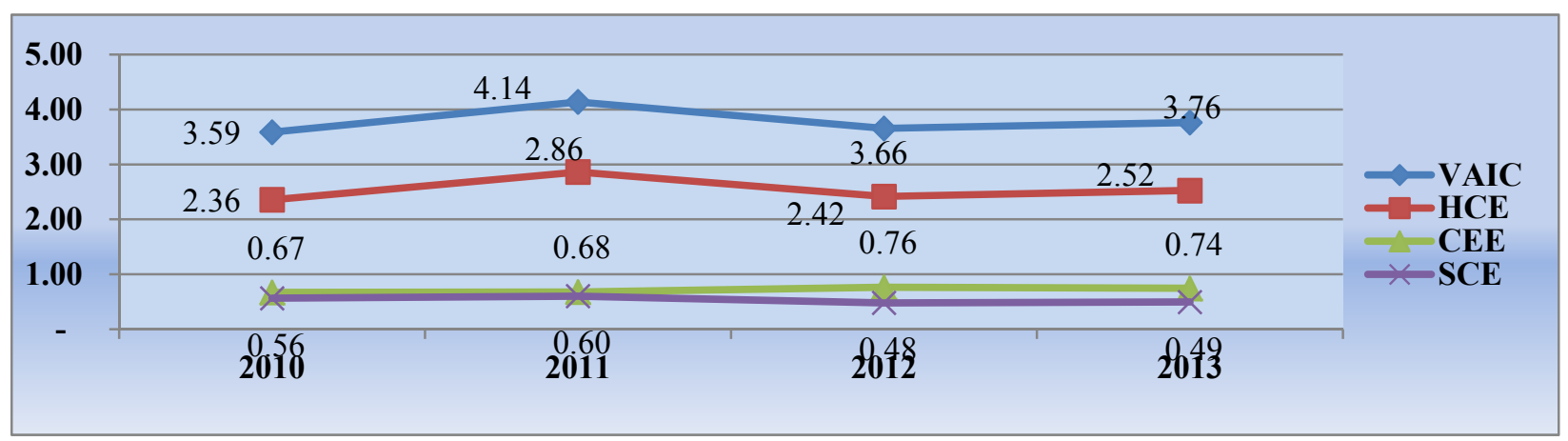

Figure 5. Trend analysis of VAIC and its components

Since VAIC ${ }^{\mathrm{TM}}$ is made up of three components, Figure $\mathbf{4}$ and Table $\mathbf{4}$ provide the disaggregation of the trend line of the $\mathrm{VAIC}^{\mathrm{TM}}$ to appreciate the influence of each component. As can be noted on Table 4, the equation of the trend lines for human capital and structural capital efficiencies suggest upward trend whereas of capital employed efficiency indicates a downward trend. As can further be noted their gradients indicates very low rates of change too. These results suggest that all the components of $\mathrm{VAIC}^{\mathrm{TM}}$ are contributing to the very low rate of change of intellectual capital efficiency, thus all three needs improvement. However since the HCE contributes significantly to $\mathrm{VAIC}^{\mathrm{TM}}$ it improvement will have relative much more impact. 
Table 4. Equation for trend lines

\begin{tabular}{llll}
\hline Variables & Mean & Standard Deviation & Trend equations \\
\hline VAIC & 3.79 & 1.28 & $\mathrm{y}=0.0041+3.37756$ \\
HCE & 2.54 & 0.97 & $\mathrm{y}=0.0057 \mathrm{x}+2.5255$ \\
CEE & 0.71 & 0.23 & $\mathrm{y}=-0.0327 \mathrm{x}+0.6151$ \\
SCE & 0.53 & 0.22 & $\mathrm{y}=0.0311 \mathrm{x}+0.635$ \\
\hline
\end{tabular}

\section{Conclusion}

The purpose of the study was to empirically measure the intellectual capital performance of the commercial banking sector of Malawi. The study used VAIC ${ }^{\mathrm{TM}}$ methodology and the performance category levels used in Kamath (2007). The results indicate that the sampled commercial banks as a whole achieved common performance over the study period except in 2011 when they achieved good performance. Furthermore trend analysis suggests an upward trend of the value of $\mathrm{VAIC}^{\mathrm{TM}}$ which is however at a very low rate, thus suggesting that there is need for much effort by the commercial banking industry to increase the rate in order to significantly improve the intellectual capital efficiency. Generally, the performance level scores seem to be very poor compared to the same for other studies in other countries. As can be noted, the score range over the period was between 6.02 and 0.96 whereas other studies give much better score range. For example Mohiuddin et al. (2006) reported a range of 16.24 and 3.98 in Bangladesh. Other examples included those that reported $\mathrm{VAIC}^{\mathrm{TM}}$ of as high as 18.695 in India (Kamath, 2007), and 14.62 in Malaysia (Goh, 2005). This further indicates that greater effort is really needed to improve the efficiency levels for the banks in Malawi.

Generally the study provides the current status of intellectual capital efficiency to assist practitioners is the banking industry in their effort to improve it. It has highlighted areas that need improvement in order to have vibrant commercial banking sector. The study has also provided confirmatory evidence of the dominance of human capital efficiency to the value of VAIC ${ }^{\mathrm{TM}}$ consistent with other prior studies (Mohiuddin et al., 2006; Mavridis, 2005; Goh, 2005; Kamath, 2007; Muhammad \& Ismail, 2009; Joshi et al., 2010). The study has indicated that human capital efficiency scores over the study period contributed about two thirds to the value of $\mathrm{VAIC}^{\mathrm{TM}}$, thus suggesting that human capital is very important factor than physical capital for banks (Yalama and Coskun, 2007). The results assent to the fact that although physical capital is essential for banks to operate, it is the intellectual capital that determines the quality of services provided to customers (Goh, 2005). Managers in the banking sector need therefore to pay necessary attention to their workforce to ensure operational buoyancy.

The study has some practical implications. It creates awareness of the status of intellectual capital performance among practitioners within the banking sector. It further suggests to the practitioners that much more effort is needed to enhance the performance of the individual banks and consequently the entire sector. Furthermore the results suggests the importance of the human element in value creation in banking industry, hence the management of banks need to pay much attention to their human capital (Wang \& Chang, 2005). Scientifically the study contributes to existing literature on intellectual capital performance especially for developing countries where there is dearth of the same (Abeysekera 2007; Khan \& Ali 2010). Furthermore it serves as a useful reference for future research especially relating to the banking sector.

The study has the following limitations. Basically VAIC ${ }^{\mathrm{TM}}$ is an accounting measure of performance as a result it does not provide an adequate framework for analysing synergy between human, structural, and physical capital (Janosević et al., 2013). Furthermore the methodology uses data from financial statements (Tan et al., 2007), as such, some differences may arise due differences in the application of accounting rules. Besides, the study was confined to the banking sector, hence the results not be generalizable to other sectors. Future studies should consider using other measures of intellectual capital efficiency as well as comparing them with VAIC $^{\mathrm{TM}}$ model and gauging more valuable output (Muhammad \& Ismail, 2009). Furthermore, future studies should endeavour to expand sample coverage to incorporate other sectors within the financial and other service sectors and carryout comparative analysis in order to have a comprehensive view of intellectual capital performance in Malawi.

\section{References}

Abeysekera I. (2007). Intellectual capital reporting between a developing and developed nation. Journal of $\begin{array}{lllll}\text { Intellectual Capital, } & 8(2), & 329-345 . & \text { Retrieved from }\end{array}$ http://www.emeraldinsight.com/journals.htm?articleid $=1602948$ 
Ahmad, S. B., \& Mushraf, A. M. (2011). The Relationship between Intellectual capital and Business Performance: An empirical study in Iraqi industry. 2011 International Conference on Management and Artificial Intelligence IPEDR Vol. 6 (2011) IACSIT Press, Bali, Indonesia. Retrieved from http://www.ipedr.com/vol6/20-A10012.pdf

Cabrita, M., \& Vaz, J. (2005). Intellectual Capital and Value Creation: Evidence from the Portuguese Banking Industry. The Electronic Journal of Knowledge Management, 4(1), 11-20, Retrieved from $\mathrm{http}: / / \mathrm{www} . \mathrm{ejkm} . \mathrm{com} / \mathrm{issue} /$ download.html?idArticle=62

F-Jardon, C. M., \& Martos, M. S. (2009). Intellectual capital and performance in wood industries of Argentina. Journal of Intellectual Capital, 10(4), 600-616. http://dx.doi.org/10.1108/14691930910996670

Gan, K., \& Saleh, Z. (2008). Intellectual Capital and Corporate Performance of Technology-Intensive Companies: Malaysia Evidence. Asian Journal of Business and Accounting, 1(1), 113-130. Retrieved from http://umepublication.um.edu.my/filebank/published_article/404/Vol1(1)-Article6.pdf

Goh, P. C. (2005). Intellectual capital performance of commercial banks in Malaysia. Journal of Intellectual Capital, 6(3), 385-396. http://dx.doi.org/10.1108/14691930510611120

Janosević, S., Dzenopoljac, V., \& Bontis, N. (2013). Intellectual Capital and Financial Performance in Serbia. Knowledge and Process Management, 20(1), 1-11, http://dx.doi.org/10.1002/kpm.1404

Joshi, M., Cahill, D., \& Sidhu, J. (2010). Intellectual capital performance in the banking sector: An assessment of Australian owned banks. Journal of Human Resource Costing \& Accounting, 14(2), 151-170. http://dx.doi.org/10.1108/14013381011062649

Joshi, M., Cahill, D., \& Sidhu, J. (2013). Intellectual capital and financial performance: an evaluation of the Australian financial sector. Journal of Intellectual Capital, 14(2), 264-285.

Kamal, M. H. M., Mat, R. C., Rahim, N. A., Husin, N., \& Ismail, I. (2012). Intellectual capital and firm performance of commercial banks in Malaysia. Asian Economic and Financial Review, 2(4), 577-590. http://www.aessweb.com/download.php?id=1465

Kamath, G. B. (2007). The intellectual capital performance of Indian banking sector. Journal of Intellectual Capital, 8(1), 96-123. http://dx.doi.org/10.1108/14691930710715088

Khan, H., \& Ali, M. (2010). An empirical investigation and users perceptions on intellectual capital reporting in banks: Evidence from Bangladesh. Journal of Human Resource Costing and Accounting, 14(1), 48-69. Retrieved from http://ssrn.com/abstract $=1910159$

Komnenic, B., \& Pokrajcic, D. (2012). Intellectual capital and corporate performance of MNCs in Serbia. Journal of Intellectual Capital, 13(1), 106-119. http://dx.doi.org/10.1108/14691931211196231

Latif, M., Malik, M. S., \& Aslam, S. (2012). Intellectual capital efficiency and corporate performance in developing countries: A comparison between Islamic and conventional banks of Pakistan. Interdisciplinary Journal of Contemporary Research in Business, 4(1), 405-420.

Lipunga A. M. (2014). A Longitudinal Assessment of Intellectual Capital of Companies Listed on Malawi Stock Exchange. European Journal of Business and Management, 6(9), 27-35.

Lipunga, A. M. (2013). Visualization of Intellectual Capital disclosures in annual reports of commercial banks of Malawi. Interdisciplinary Journal of Contemporary Research in Business, 5(3), 155-169. Retrieved from http://journal-archieves34.webs.com/155-169.pdf

Litschka, M., Markom, A., \& Schunder, S. (2006). Measuring and analysing intellectual assets: an integrative approach. Journal of Intellectual Capital, 7(2), 160-173. http://dx.doi.org/10.1108/14691930610661836

Maditinos, D., Šević, Ž., \& Tsairidis, C. (2009). Intellectual Capital and Business Performance: An Empirical study for the Greek Listed Companies. 7th International Conference on Accounting and Finance in Transition (ICAFT) 23-25 July 2009 Greenwich, London organised by Greenwich University, The Business School. Retrieved from http://www.researchgate.net/publication/227430845_Intellectual_Capital_and_Business_Performance_An_ Empirical_Study_for_the_Greek_Listed_Companies/file/60b7d514b490348ce2.pdf

Masud, M. A. K., \& Hossain, M. S. (2012). Corporate Social Responsibility Reporting Practices in Bangladesh: A Study of Selected Private Commercial Banks. IOSR Journal of Business and Management, 6(2), 42-47. Retrieved from http://iosrjournals.org/iosr-jbm/papers/Vol6-issue2/G0624247.pdf 
Mavridis, D. G. (2004). The intellectual capital performance of the Japanese banking sector. Journal of Intellectual Capital, 5(1), 92-115. http://dx.doi.org/10.1108/14691930410512941

Mavridis, D. G. (2005). Intellectual Capital Performance Drivers in the Greek Banking Sector. Management Research News, 28(5), 53-62. http://www.emeraldinsight.com/journals.htm?articleid=1514873

Mention, A., \& Bontis, N. (2013). Intellectual capital and performance within the banking sector of Luxembourg and Belgium. Journal of Intellectual Capital, 14(2), 286-309. http://dx.doi.org/10.1108/14691931311323896

Mohiuddin, M., Najibullah, S., \& Shahid, A. I. (2006). An Exploratory Study on Intellectual Capital Performance of the Commercial Banks in Bangladesh. The Cost and Management, 34(6), 40-54. Retrieved from http://www.icmab.org.bd/index.php?option=com_docman\&task=doc_download\&gid=22

Mondal, A., \& Ghosh, S. K. (2012). Intellectual capital and financial performance of Indian banks. Journal of Intellectual Capital, 13(4), 515-530. http://dx.doi.org/10.1108/14691931211276115

Muhammad, N. M. N., \& Ismail, M. K. A. (2009). Intellectual Capital Efficiency and Firm's Performance: Study on Malaysian Financial Sectors. International Journal of Economics and Finance, 1(2), 206-212. Retrieved from http://www.ccsenet.org/journal/index.php/ijef/article/view/3399/3080

Phusavat, K., Comepa, N., Sitko-Lutek, A., \& Ooi, K. (2011). Interrelationships between intellectual capital and performance: Empirical examination. Industrial Management \& Data Systems, 111(6), 810-829.

Puntillo, P. (2009). Intellectual Capital and business performance. Evidence from Italian banking industry. Журнал "Корпоративные Финансы, 4(12), 97-115.

Reserve Bank of Malawi. (2010). Bank Supervision Department Annual Report 2010. Retrieved from $\mathrm{http} / / / \mathrm{www} . \mathrm{rbm} . \mathrm{mw} /$ documents/basu/BANK\%20SUPERVISION\%20ANNUAL\%20REPORT\%202010.pd $\mathrm{f}$

Reserve Bank of Malawi. (2011). Bank Supervision Department Annual Report 2011. Retrieved from https://www.rbm.mw/documents/basu/RBM\%20Bank\%20Supervision\%202011\%20Report.pdf.

Reserve Bank of Malawi. (2012). Bank Supervision Department Annual Report 2012. Retrieved from http://www.rbm.mw/documents/basu/RBM\%20BASU\%20ANNUAL\%20REPORT\%202012.pdf

Tan, H. P., Plowman, D., \& Hancock, P. (2007). Intellectual capital and financial returns of companies. Journal of Intellectual Capital, 8(1), 76-95, http://dx.doi.org/10.1108/14691930710715079

Ting, I. W. K., \& Lean, H. H. (2009). Intellectual capital performance of financial institutions in Malaysia. Journal of Intellectual Capital, 10(4), 588-599. http://dx.doi.org/10.1108/14691930910996661

Tseng, C., \& Goo, Y. J. (2005). Intellectual capital and corporate value in an emerging economy: empirical study of Taiwanese manufacturers. R\&D Management, 35(2), 187-201. Retrieved from http://onlinelibrary.wiley.com/doi/10.1111/j.1467-9310.2005.00382.x/pdf

Wang, W., \& Chang, C. (2005). Intellectual capital and performance in causal models Evidence from the information technology industry in Taiwan. Journal of Intellectual Capital, 6(2), 222-236. http://dx.doi.org/10.1108/14691930510592816

Yalama, A., \& Coskun, M. (2007). Intellectual capital performance of quoted banks on the Istanbul stock exchange market. Journal of Intellectual Capital, 8(2), 256-271. http://dx.doi.org/10.1108/14691930710742835

\section{Copyrights}

Copyright for this article is retained by the author(s), with first publication rights granted to the journal.

This is an open-access article distributed under the terms and conditions of the Creative Commons Attribution license (http://creativecommons.org/licenses/by/3.0/). 